\title{
Research on the Applications of Mind Mapping in Writing Teaching of College English
}

\author{
Lujuan Huang \\ College of Humanities, Xi'an International University, Xi'an, 710077, China
}

Keywords: Mind mapping, Writing teaching, College English.

\begin{abstract}
Mind mapping, as a new means of training students' divergent thinking, can help students to stimulate interest in English learning and develop comprehensive ability in English writing. In the process of writing teaching of college English, the use of mind mapping can form visual teaching effects and improve student's thinking ability. This paper analyzes the application forms of mind mapping before the wring class, during the writing class and after the writing class to provide some references for the relative researchers.
\end{abstract}

\section{Introduction}

Writing is a compulsory item in English test. We ask the candidates to write a short passage in several minutes based on the situation given. We should be able to use English grammar accurately according to the specific context and choose the proper vocabulary. Students should be able to use certain sentence patterns, vocabulary, clear and coherent expression of their meaning, content integrity, text coherence, no major language errors. The writing in English learning is important however, the teaching of college English writing has many problems, such as students' thinking is narrow, unable to write; lack of vocabulary, sentence stiff; lack of logic, unclear levels; grammatical errors, ideographic chaos and so on. In addition, teachers ignore students' writing ability training, the traditional teaching, boring, follow the routine explanation, examples, exercises or correcting "consistent pattern, students both in content and form have no right to speak, in the writing of the state was bound hand and foot, don't talk about creative writing. Therefore, students of writing uninterested, written expression became a big problem in English teaching, the students are afraid of writing, teachers are as pain. How to effectively improve the quality of English writing teaching, make the English writing class full of vigor and vitality, and better promote the development of students' writing ability, is a hot topic that many teachers and researchers pay close attention to. Generally, the actual situation of the students from the teacher, the choice of teaching methods and the appropriate method to build the teaching platform, stimulate students' interest in writing, improve their writing level and innovation ability, finally realize the way of learning English to autonomous learning, individualized learning has changed the meaning of learning, and the mind map is an important means to achieve this target.

\section{Concept, Features and Theory Basis of Mind Mapping}

Concept of Mind Mapping. The mind map is by the ways of teaching and training a system developed by the famous scholar Anthony of Britain, and with the development and further, the mind map has gradually become one of the most influential training model in the world. Think map training is based on mental and Chile's development, the structural model and the graphic form of mesh to the technical processing, using key words and images formed by training, make better storage knowledge, inspire to achieve memory. The divergent thinking mode can be regarded as a central sphere, and around the center of the sphere is countless Lenovo, Lenovo itself between these are inextricably linked, forming a huge network of relationships is consistent with this model, the brain is stimulated, 
mind map. The mind map will make full use of the left and the right brain, the logic, words, images, color and other factors combined, and participate in the whole process of thinking and memory, on the other hand, it is the utilization of the graphical model of the mind map can record the whole process and guide in the process of thinking, maximize the divergent thinking of human brain play visual expression. Trainers need to take more responsibility in the process of training is to guide, help them to the urgent need to strengthen the memory formation trigger, to stimulate the training potential, make it a potential field to get the maximum. In the construction of mind map, we can make full use of color, lines, graphics and other cortical functions to stimulate the brain, to carry out the whole brain thinking. Therefore, mind mapping is a way of presenting thought processes and results in an intuitive way. It is also an effective tool for graphic thinking.

Features of Mind Mapping. The mind map has many features. These different features are combined to achieve simple and prominent, and can help strengthen the mind map and the brain image thinking combined, let the sides of the brain to maximize play, greatly improve the learners in intelligence and the use of skills, strengthen the focus of knowledge the study of absorption. The memory map is produced in the context of the comprehensive memory of the human brain. The linear image of the human brain unfolds in human thinking, thus forming the overall expression of brain consciousness. Guided by the divergent consciousness of mind mapping, learners will think in different directions and angles, and meet the needs of the existing knowledge system, life experience and thinking paradigm. Under the guidance of hierarchy of mind mapping, it can strengthen the memory, clear understanding of different branches, easier to grasp the overall sense of thinking, and strengthen the service needs of divergent thinking. College English writing course is an important part of College English writing teaching, plays an important role in cultivating students' language habits and improve the ability of knowledge, the mind map mode, to form effective English writing tools, combined with the teaching practice in the theoretical basis, can help students through think map thinking to guide the comprehensive progress, improve the overall ability. As an effective thinking technique, mind mapping can help students realize self-cognition, facilitate individual communication, record the thinking process, and achieve clear and clear visual expression.

Theory Basis of Mind Mapping. Modern brain science has found that there are about one trillion brain cells in each person's brain. Every brain cell contains a complex, through the synapse or synapses between brain cells and brain cells, so that each individual brain cells can contact more than 10 thousand brain cells at the same time with the adjacent. They represent a network of discrete structures that form a powerful information processing and delivery system. The structure of brain cells makes possible the creation of infinite patterns and patterns in human thinking. Divergent thinking reflects the inner structure and process of the human brain. The mind map as the brain of divergent thinking outside the mirror, series allow unlimited, it conforms to the structure characteristics of the human brain's natural way of thinking, nature is of positive significance to human learning and innovation. As a kind of knowledge visualization tools, mind map is not only in conformity with the thinking process of human nature, helps to stimulate the brain potential, but also with the way the visual expression of explicit knowledge in human existence, in their own thinking and help to construct knowledge at the same time, has become an effective way to communicate and communication. According to the theory of meaningful learning, learning is meaningful only when the new knowledge represented by the symbol establishes an impersonal and substantive connection with the proper ideas already existing in the learner's cognitive structure. In other words, meaningful learning is the process by which learners actively construct knowledge networks through the connection of old and new knowledge. In this process, meaningful learning can occur only when learners actively integrate new knowledge into existing cognitive structures in their minds. As far as mind map is concerned, its creative process itself belongs to a creative thinking activity. Learners must actively seek the link between new knowledge and existing knowledge, and construct a good structure for organizing and characterizing knowledge. This is the essential activity of meaningful learning. 


\section{Applications of Mind Mapping in the Writing Class of College English}

Applications of Mind Mapping before the Writing Class of College English. The mind map as an effective means of Teaching College English writing course, emphasizing on cultivating the consciousness of teaching thinking in the process of education, pay attention to the analysis of whole knowledge, help the students to improve thinking space, broaden the application value to college English writing and students' knowledge integration management system, the formation of more thinking of using value. The mind map can be adopted to simulate the situation of interesting way to form interesting English activities to attract the attention of students, such as the expansion of the life oriented teaching of classroom teaching mode, English learning and the combination of real life, from life to make the students feel the charm of English, from writing feel English is closely linked with our life. Mind mapping can stimulate students' comprehensive application ability, cultivate students' comprehensive interest and enhance their overall ability, thus enhancing the efficiency of the whole classroom learning and consolidating the learning effect. The teachers in the process of planning, in access to relevant information, and colleagues research group to actively explore the teaching objectives and teaching points at the same time, can use mind map guide, recording, arrangement and induction of their own and other people's views and teaching ideas, and teaching design, teaching courseware, fully prepared classroom teaching. For students, the application of mind mapping in front of the class mainly refers to the preparation and auxiliary function of the writing materials. The students in the process of preparation the writing materials, writing understanding and thinking at the same time, can use mind map from the textual theme, structure, content, text difficulty and language difficulties and sort out their organizational knowledge and questions, preliminary writing materials, they have already mastered the content and clear to further understand and understand the contents into the classroom learning with questions. This is of great significance to overcome the shortcomings of the traditional linear pen, and to improve the enthusiasm and learning effect of students.

Applications of Mind Mapping during the Writing Class of College English. At the beginning of teaching, teachers can use mind mapping to organize brainstorming activities, and adopt a teacher led, student oriented approach, and actively guide and encourage students to think. Between teachers and students, between students and students can freely express their views on the theme and writing materials, or can communicate and guess writing materials related to the content, to demonstrate their understanding of the writing materials from different angles. The teachers and students based on discussion, to jointly build a mind map, to organize and organize teachers and students view, starting from the whole, play a role in the advance organizer, expand and enrich the students' cognition at the same time, laid the foundation for further writing materials. Secondly, in the middle stage of the teaching, mind mapping can be used to organize and display the content of the teaching, and to facilitate the communication and communication between teachers and students, and to facilitate the students to understand and grasp the writing materials. At the same time, the open structure of mind map makes it possible for teachers to adjust and perfect their teaching content flexibly and flexibly according to the actual teaching situation and class requirements. Thirdly, mind mapping can be used as formative evaluation tool. By observing the students' designing and making mind mapping process, teachers can understand their writing materials, content and teaching difficulty, so that they can give timely diagnosis to improve teaching. For students, the application of mind mapping in class mainly refers to its auxiliary function to the learning process. Students can according to the teaching content of teachers' use of mind mapping in notes, notes based on according to their own understanding and meaning construction of writing materials, writing materials using theme, structure or heavy and difficult to organize and construct the mind map visualization to express their ideas.

Applications of Mind Mapping after the Writing Class of College English. Teacher's writing thinking habit influences the writing thinking habit of students to a certain extent. Therefore, in the process of teaching, teachers need to grasp each student's thinking habits and thinking characteristics, as much as possible to help students change habits of thinking habits. For teachers, the application of mind map after class mainly refers to its role as a tool for teaching reflection, a summative assessment 
tool and a tool for teaching and research. After the end of classroom teaching, teachers should reflect on the actual situation of teaching! Revision and redesign teaching, through the continuous improvement of the mind mapping process, and ultimately improve teaching. Secondly, teachers can use mind mapping as a summative evaluation tool for students' learning. The result of mind map is an image representation of the knowledge structure in the student's mind, which can help the teacher understand the students' grasp of the writing materials more truly. Thirdly, teachers can use mind mapping to analyze the factors involved in writing teaching and learning, sum up teaching experience, study the law of writing teaching activities, and lay a foundation for better writing course teaching. For students, the application of mind mapping after class mainly refers to its role as a learning tool and a summary review tool. First, after the end of classroom teaching, students can use the already constructed mind map to reflect and review the teaching content and difficulties. You can think more about it based on discussion and negotiation with others, through constant reflection on mind map! Revise and redesign gradually learn to reflect on their learning process, improve their learning efficiency and quality. Secondly, students in extra-curricular writing, not only can use think map help thinking and record yourself and others opinions and views, also can use the mind map and finishing their knowledge structure, lay the foundation for promoting their cognitive level and establish a complete knowledge system.

\section{Conclusion}

The application of mind mapping in the teaching of English writing has trained students' thinking. Let students no longer adhere to the thinking set, and learned to use divergent thinking, thinking problems. The mind map requires students to try, independent rendering, so the College English writing teaching guided by thinking, which can arouse the enthusiasm of the students and active classroom atmosphere, and cultivate students' autonomous learning ability through this way. The application of mind mapping in college English writing course can effectively improve student's writing ability.

\section{Acknowledgements}

This paper is the result of the Subject of "the 13th Five-Year" Plan of the Education Science of Shaanxi in 2016 named "Research on the Effect of Writing Teaching Based on Conceptual Metaphor Theory on English Writing Ability of College Student” (Grant No. SGH16H280).

\section{References}

[1] Jia Hong. Application of Mind Map in the Network College English Teaching [J]. Journal of Changchun Normal University (Humanities and Social Science), 2014, 33(2): 169-171.

[2] Li Ya. Application of Mind Map in the Teaching of College English Reading Course [J]. Overseas English, 2015(24): 44-45+59.

[3] Han Ying, Bao Jiping, Wu Aihua. Study on English Writing of Senior High School by Using Mind Map [J]. Value Engineering, 2012(30): 266-268.

[4] Shu Xiaoyang. An Empirical Research of Application of Mind Map into English Writing Teaching [J]. Journal of Harbin University, 2009, 30(5): 116-121. 